\title{
Professional Needs in Negro Colleges
}

Mr. Marshall is librarian, Lincoln University (Missouri).

The Recruiting Committee of the A.C.R.L., at a meeting in February, 195I, asked to have a survey made of the existing and future needs of Negro colleges and universities for professional librarians. It was suggested that a sub-committee be formed to make the survey and that the report be ready by the summer meeting of the American Library Association. Selected to serve on the sub-committee were: Mrs. Leola M. Ross, Librarian, Winston-Salem Teachers College, Winston-Salem, North Carolina; Paul M. Smith, Librarian, Dillard University, New Orleans, Louisiana; Miss Frances V. Smith, Librarian, Texas College Library, Tyler, Texas; Mrs. Mary M. Turner, Assistant Librarian, Lincoln University, Jefferson City, Missouri. A. P. Marshall, a member of the A.C.R.L. committee acted as chairman. ${ }^{1}$

Questionnaires were sent to a total of 58 institutions and were returned by $4 \mathrm{I}$ (70 per cent). Many of the returns indicated that no vacancies existed at the present or in the foreseeable future. Fifty-one vacancies were reported, ranging from administrative or highly technical positions to general assistantships. Since no effort was made to determine which of the positions required specific training, it can only be reported that most of the reporting institutions do prefer some technical knowledge for the positions indicated. Typing is regarded as necessary by 18 of those reporting; education 12 ; social science, $\mathrm{II}$; humanities, 8 ; French, 6 ; science, 6 ; Spanish, 3 ; journalism, 1 .

Only 39 percent of the salaries offered for

${ }^{1}$ Copies of the full report of the sub-committee are available from A. P. Marshall, Lincoln University Library, Jefferson City, Missouri. professional librarians were above the A.L.A. Minimum Standards. Most of them ranged from $\$ 2$, I0o to $\$ 3,000$.

New graduates of library schools would be acceptable by 26 of the colleges reporting, while 4 indicated otherwise. Other information checked by the latter seemed to indicate that more experience was desired for the positions open. A man would be preferable to a woman in only one of the positions, while 25 indicated that either would be acceptable. Two colleges would prefer women.

In answer to the question of whether race would be a factor in the employment of professional librarians, 17 indicated that it would, while Io reported that it would not. Those reporting in the affirmative are notably in the deep south, while those indicating a negative answer are either outside of the South or in border states.

There are 137 trained librarians in the $4 \mathrm{I}$ institutions reporting, the highest number being $2 \mathrm{I}$, the second highest, $\mathrm{I} 2$. Most of the institutions ranged between I professional (13) and 2 professionals (8).

Librarians filled out the questionnaires for 26 of the reporting institutions. Presidents filled them out in 12 ; the president's secretary, I ; and the dean, I.

Number of vacancies reported for each of the major professional positions were:

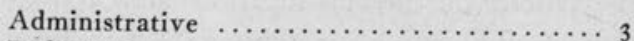

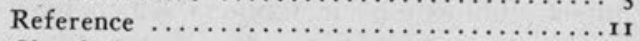

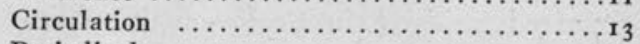

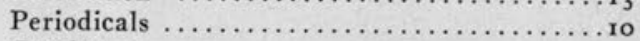

Catalogers ........................

Reference-Circulation $\ldots \ldots \ldots \ldots \ldots \ldots \ldots \ldots \ldots \ldots$

General Assistant .................. 2

Research and Readers Adviser ........... $\mathbf{r}$

Law $\ldots \ldots \ldots \ldots \ldots \ldots \ldots \ldots \ldots \ldots \ldots \ldots \ldots \ldots \ldots \ldots \ldots \ldots \ldots$

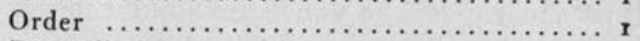

Journalism ..............

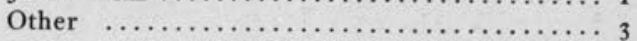

